The Philosophical Journal of Conflict and Violence

Vol. III, Issue $1 / 2019$

(C) The Authors 2019

Available online at http://trivent-publishing.eu/

\title{
In the Land of Blood and Honey: A Cinematic Representation of the Bosnian War
}

\author{
Dubravka Zarkov, ${ }^{1}$ Rada Drezgic ${ }^{2}$ \\ ${ }^{1}$ Radboud University, Nijmegen, The Netherlands \\ ${ }^{2}$ University of Arts, Belgrade, Serbia
}

\begin{abstract}
This paper addresses the representation of violence in the film In the Land of Blood and Honey, which was directed by Angelina Jolie (2011). Internationally hailed, awarded but also bugely criticized, the film purports to be about rape camps where Muslim women were held and assaulted by Bosnian Serb forces during the Bosnian war. However, the film merges the story of rape camps with a story about a (sexual) relationship between an incarcerated Muslim woman and a Serb camp commander. Our paper analyzes the cinematic tools used to tell these two stories, focusing on what is referred to as borrowing, and suggests that Jolie borrowed liberally to tell her story. The article focuses on three types of borrowing, cinematic, literary and experiential, and looks at three visual cinematic tropes obtained from Holocaust movies, Cold War movies, and ex-Yugoslav cinematic productions. It is concluded that the film recycles an already largely discarded narrative of "a history of ethnic hatred" as prime cause of war in the former Yugoslavia. The film's director thus misses an opportunity to challenge the ethnicization of the region - something many local film directors have already successfully achieved.
\end{abstract}

Keywords: Bosnia; Cinematic Representations; Ethnicity; Gender; Ontological Subject Position; Violence; War.

DOI: 10.22618/TP.PJCV.20193.1.192010

The PJCV Journal is published by Trivent Publishing

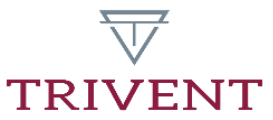

This is an Open Access article distributed in accordance with the Creative Commons Attribution Non Commercial (CCBY-NC-ND 4.0) license, which permits others to copy or share the article, provided original work is properly cited and that this is not done for commercial purposes. Users may not remix, transform, or build upon the material and may not distribute the modified material (bttp:/ / creativecommons.org/licenses/by-nc/4.0/) 


\title{
In the Land of Blood and Honey: A Cinematic Representation of the Bosnian War
}

\author{
Dubravka Zarkov, ${ }^{1}$ Rada Drezgic ${ }^{2}$ \\ ${ }^{1}$ Radboud University, Nijmegen, The Netherlands \\ ${ }^{2}$ University of Arts, Belgrade, Serbia
}

\begin{abstract}
This paper addresses the representation of violence in the film In the Land of Blood and Honey, which was directed by Angelina Jolie (2011). Internationally hailed, awarded but also hugely criticized, the film purports to be about rape camps where Muslim women were held and assaulted by Bosnian Serb forces during the Bosnian war. However, the film merges the story of rape camps with a story about a (sexual) relationship between an incarcerated Muslim woman and a Serb camp commander. Our paper analyzes the cinematic tools used to tell these two stories, focusing on what is referred to as borrowing, and suggests that Jolie borrowed liberally to tell her story. The article focuses on three types of borrowing, cinematic, literary and experiential, and looks at three visual cinematic tropes obtained from Holocaust movies, Cold War movies, and ex-Yugoslav cinematic productions. It is concluded that the film recycles an already largely discarded narrative of "a history of ethnic hatred" as prime cause of war in the former Yugoslavia. The film's director thus misses an opportunity to challenge the ethnicization of the region - something many local film directors have already successfully achieved.
\end{abstract}

Keywords: Bosnia; Cinematic Representations; Ethnicity; Gender; Ontological Subject Position; Violence; $W$ ar.

\section{Introduction}

Since the former Yugoslavia disintegrated through wars (1991-1995, and 1999), there has been considerable cinematic production within its successor states, dealing with the wars and the post-war dynamics. These productions have received substantial national, regional and international attention, and a few films received major international awards. ${ }^{1}$

The wars of the former Yugoslavia have also been a theme in international productions, be it as a side-plot in (both high- and low-rating) US and UK television crime series, or in feature films of various genres and variable quality. ${ }^{2}$ Other countries, whose militaries have participated in the UN peacekeeping forces, have also contributed to cinematic productions on the wars in the former Yugoslavia. ${ }^{3}$

\footnotetext{
${ }^{1}$ See, for example, Kusturica (Underground, 1995), Dragojevic (Pretty Village, Pretty Flame, 1996), Tanović (No Man's Land, 2001), Zbanić (Grbavica, 2006 / Land of My Dreams in US/ Esma's Secret in UK), Begić (Snow, 2008).

${ }^{2}$ The number of US and UK film productions (and co-productions with ex-YU film houses) is too great to be listed here. Among the better-known examples is Michael Winterbottom's Welcome to Sarajevo (1997, UK).

${ }^{3}$ Examples of films include the Spanish Comanche Territory (1997), by Gerardo Herrero; the Polish Demons of War (1998), by Władysław Pasikowski; the Pakistani TV mini-series Alpha Bravo Charlie (1998) by
} 
A film that caused some controversy and attracted media interest is Angelina Jolie's In the Land of Blood and Honey (2011). Hailed, awarded but also strongly criticized (in Bosnia, the US and Serbia respectively), the film purports to be about rape camps where Muslim women were held and systematically raped by Bosnian Serb forces in 1992-1993, during the Bosnian war. However, the film merges the story of rape camps with a story about a (sexual) relationship between an incarcerated Muslim woman and a Serb camp commander.

We analyze the cinematic and narrative tools used to tell these two stories, focusing on borrowing. We suggest that Jolie liberally borrowed from elsewhere in order to tell her story. Thanouli argues that in the last two decades some film directors have used "eclectic irony" by parodying famous scenes from cult films, thus creating critical distance between the (different) narratives. ${ }^{4}$ Our argument is that Jolie, quite to the contrary, integrates into her own story the tropes of specific genres in an attempt to create or strengthen the authenticity of her own cinematic narrative. We focus on three types of borrowing, cinematic, literary and experiential. Regarding cinematic borrowing, we look at three visual tropes obtained from Holocaust movies, ex-Yugoslav cinematic productions of the late 1960s and 1990s, and Cold War movies. We also analyze Jolie's use of some of the most famous sentences from classical literature, and finally we look at how experiences of sexual violence in wars from other regions are transported to Bosnia.

Our conclusion is that Jolie recycles an already largely discarded narrative of "a history of ethnic hatred" as the main cause of the war in the former Yugoslavia, thus missing an opportunity to challenge the ethnicization of the region, something many local film directors have already successfully done. We use the concept of ethnicization to dispute the essentialist understanding of identity and stress the importance of socio-political processes by which people, histories and territories become reduced to a single, identitarian ethnic belonging and as an ontological category. ${ }^{5}$ Since the mid-1980s nationalists in the former Yugoslavia elevated ethnicity to a single mode of being, denying and destroying other possibilities of self-reference. While in the past ethnicity was only one of many ways in which people would define themselves, nationalist narratives and the wars through which socialist Yugoslavia disintegrated defined it as an essentialist, "blood-and-soil" category of belonging. Once people were reduced to ethnicity, so were the histories and territories. Narratives of historical injustices and victimization based on ethnicity were accompanied by territorial claims for one's own population, and ultimately by violent strategies of expulsion and destruction. Another aspect of

Shoaib Mansoor. Documentaries about Kenyan and Portuguese peacekeepers, respectively, include Thomas Balmes's Bosnia Hotel: Kenyan Warriors in Bosnia (1997) and Joaquim Sapinho's Bosnia Diaries (2005). In some other countries, the Yugoslav wars from the 1990s were the theme of television rather than film production. This is the case with the UK Warriors (1999), screened in the US cinemas under the title Peacekeepers. See Dubravka Žarkov, "Warriors: Cinematic Ontologies of Bosnian War," European Journal of Women's Studies 21/2 (2014): 180-193. The Dutch have also made a mini-series De Enclave (2002), which focused on the Srebrenica genocide and its aftermath. See Dubravka Žarkov, "Cinematic Representations of the Bosnian War: De Enclave and the Ontologies of Unrecognizability," in Post-Yugoslavia. New Cultural and Political Perspectives, ed. Abazovic, D. and M. Velikonja (London: Palgrave MacMillan, 2014), 162-197.

${ }^{4}$ Eleftheria Thanouli, "Post-Classical Narration. A New Paradigm in Contemporary Cinema," New Review of Film and Television Studies 4/3 (2006):183-196.

${ }^{5}$ For a detailed discussion on ethnicization in the former Yugoslavia, and for mainstream and feminist writing on it, see Dubravka Žarkov, The Body of War: Media, Ethnicity and Gender in the Break-up of Yugoslavia (Durham and London: Duke University Press, 2007). 
ethnicization is collectivization: an individual person stands for the collective. Thus, for example, in Serbia, there were many discussions of who is "the real Serb," and "Serbhood" was denied to draft-dodgers and to gay men.

Sadly, it was not only nationalists who perceived the peoples of the former Yugoslavia exclusively through an essentialist ethnic lens. Academic and cultural productions often adopted the same position. Many authors never asked through which socio-political processes ethnicity had become a privileged ontological category, nor what had been erased when ethnicity became the privileged (and often the only) mode of being. Consequently, "ethnic hatred" became an easy explanation for the war, especially in the beginning of the conflict.

We want to point out two (among many) problems with such an ontological reductionism. First, not everybody in the former Yugoslavia was nationalist. Even in the midst of the war many people refused to accept that ethnicity was the only way to define themselves, the only measure of their own or others' human worth. Second, the reference to ethnicity - even for nationalists - has been highly problematic and in constant need of defense and strengthening. After all, in the census of the former Yugoslavia, "Muslim" was treated as an ethnic, not just religious, belonging. Thus, while on the one hand nationalists, together with many academics and cultural narratives, continuously referred to "the Serbs," "the Croats" and "the Muslims" in essentialist, biological, almost racial terms, there was, on the other hand, a struggle by many individuals, groups and organizations to show that such ontological positioning of people is unacceptable, and ultimately unattainable. Cultural production - literature, theatre and film both reproduced and resisted ethnicization. Film (regional and international) production was an especially important site where ethnicization was reinforced as well as interrogated. ${ }^{6}$

In Angelina Jolie's film such interrogation is absent, and - we argue - ethnicity is reinforced as an ontological category, as an inevitable and unavoidable mode of being. The protagonists of her film are "the Serbs" and "the Muslims", each endowed with gendered characteristics fitting the long-dominant, mainstream political discourses of "the Serbs" as ultimate aggressors and "the Muslims" as ultimate victims. The story about war-camp rape may be difficult to tell without essentializing "the Serb rapist" and "the Muslim rape victim," but some filmmakers have successfully done it. ${ }^{7}$ Thus, it is within the capacity of a screenwriter and director to challenge ethnicization, rather than create a cinematic narrative and protagonists that endorse it.

Following Jazairy's assertion that specific places "condition and determine the film's narrative structure," 8 we argue that Jolie approached Bosnia and its population through the prism of what Bakic-Hayden and Hayden have called the "symbolic continent" of the Balkans: a specific, isolated place, whose singular, violent geography is separated from (peaceful, rational and modern) Europe and the west. ${ }^{9}$ This representation is part of a larger set of Orientalist

\footnotetext{
${ }^{6}$ For a discussion on films reinforcing and resisting ethnicization see Milena Marinkova, "Po-co-co Balkans. Dancing Bears and Lovesick Donkeys, Bouncing Mines and Ethnic Conflict in Two Films from the Region," Third Text 24/ 4 (2010):457-469; Jurica Pavičić, "Cinema of Normalization': Changes of Stylistic Model in post-Yugoslav cinema after the 1990," Studies in Eastern European Cinema 1/1 (2010): 43-55; Stephen Harper, "'History is Screaming at Us': Humanitarian Interventionism and the Popular geopolitics of the Bosnian War in Leigh Jackson and Peter Kosimnsky's Warriors," Review article (16 June 2011), http://www.relativeautonomy.com/2/post/2011/06/history-is-screaming-at-us-humanitarian-interventionism-and-the-popular-geopolitics-of-the-bosnian-war-in-leigh-jackson-and-peterkosminskys-warriors.html (accessed 6 June 2011).

7 See, for example, Zbanic's Grbavica (2006).

${ }^{8}$ El Hadi Jazairy, "Cinematic Landscapes in Antonioni's L'Aventura," Journal of Cultural Geography 26/3 (2009): 351-369.

${ }^{9}$ Milica Bakic-Hayden \& Robert M. Hayden, "Orientalist Variations on the Theme 'Balkans': Symbolic Geography in Recent Yugoslav Cultural Politics," Slavic Review 52/1 (1992):1- 16.
} 
and Balkanist discourses, through which Serbia and Bosnia (unlike Croatia and Slovenia) were regularly represented since the start of the war in early 1990s. ${ }^{10}$ In an interesting twist, however, Jolie associates Bosnian Muslims - who tended to be Orientalized in political discourses and cultural production both within the former Yugoslavia and internationally - with the west, leaving only Bosnian Serbs in the grip of backwardness, traditionalism and the perpetration of violence.

Before proceeding to analyze the film we reflect briefly on the disintegration of Yugoslavia and the war in Bosnia, with specific attention to the context of violence relevant to understanding the film.

\section{War crimes in Bosnia and international non-intervention}

The wars of Yugoslav disintegration started in 1991, following decades of growing nationalisms and various processes that led to the secession and declaration of independence (initially) of its three former republics: Slovenia and Croatia on 25 June 1991, and Bosnia and Herzegovina on 15 October 1991.

Within a few months after its secession, Bosnia and Herzegovina was partitioned into several sections: towards the end of 1991 Herzeg Bosna was declared the homeland of the Bosnian-Croat population, while between February and August 1992, Republika Srpska was created for the Bosnian-Serb population.

The objective and driving force of those partitions was the creation of territories with a mono-ethnic population in the region, within which ethnicization had already taken hold. The tools for achieving this objective were both physical and symbolic violence. Strategies of physical violence included wide-spread destruction, expulsion and massacres of the population, sexual violence against women and men, especially in the war camps and, finally, genocide. Strategies of symbolic violence included erasure of all public traces and memories of multi-ethnicity and togetherness and of the presence of specific groups within specific territories, be it through language, school curricula or street names. Equally important were polarized, essentialized and demonized cultural representations of the Other in the media, film and literature. Physical and symbolic violence often went hand in hand: religious buildings, historical monuments and cultural heritage were deliberately targeted for physical destruction precisely because of their symbolic value.

In the summer of 1992, the news about war camps and the mass rape of women in Bosnia and Herzegovina and Croatia started appearing in the national and international media. Soon it became clear that women were systematically being raped in this war. This was part of the

The literature that analyses the production of difference between the west and its multiple Others, in political and cultural discourses and the media, is too vast to list here. Clearly, Said's (1994; and 2004) Orientalism is a seminal work that inspired many feminists and other critical authors. See Edward Said, Orientalism (New York: Vintage Books, 1994); Edward Said, "Orientalism Once More," Development and Change 35/5 (2004):869-879. Such critical analyses have received a new impetus after the 2001 terror attacks on the US and the ensuing "war on terror", and then again after revelations of sexual torture of Iraqi prisoners by US prison guards in Abu Ghraib, in 2003. Particularly inspiring for this paper is work by Judith Butler, "Sexual Politics, Torture, and Secular Time," The British Journal of Sociology 59/1 (2008): 1-23 ; John Heathershaw \& Daniel Lambach, "Introduction: Post-Conflict Spaces and Approaches to Statebuilding," Journal of Intervention and Statebuilding 2/3 (2008): 269-289.

10 Todorova has coined the term "Balkanism" to mark associations of primitivism, violence and masculinity of the Balkan region, its people, culture and history in western cultural and political representations. See Maria Todorova, Imagining the Balkans (Oxford: Oxford University Press, 1997). 
expulsion strategies termed "ethnic cleansing"11 in Bosnia, predominantly deployed by Bosnian Serb forces and their allies against the Muslim civilian population, but also utilized by Bosnian Croat and Muslim forces (in both Croatia and Bosnia). Several fact-finding missions were eventually sent to Bosnia (and Croatia) to investigate the reports, ${ }^{12}$ and numerous nongovernmental, civic and women's organizations and groups worked both on collecting testimonies and offering psycho-social support to women rape survivors. ${ }^{13}$ The establishment of the International Criminal Tribunal for the former Yugoslavia (ICTY) in 1993 has often been linked to the world's outrage and feminist activism regarding rape during the war in Bosnia. Thanks to the strenuous work done by many, and especially by women's groups and feminist lawyers involved in the process of the establishment of the ICTY, wartime rape has - for the first time in history - become a separate and specific war crime (previously appearing under the headings of "grave breaches" and "crimes against humanity").

\section{A short note on the narrative plot and the film's reception}

Rape remains one of the most notorious aspects of the war in Bosnia and has been part of cinematic narratives both of local and international feature films. ${ }^{14}$ As noted, In the Land of Blood and Honey takes the war camps and rape as one of its central narrative elements.

The film is about Ajla, a young Muslim woman from Sarajevo. She is a successful painter - one of her works is exhibited in the National Museum. She meets a young Serb policeman, Danijel, and starts a relationship with him. As the war begins, she, along with other civilians, is taken to a war camp where Danijel is a commander. They continue their relationship in the camp, and later, after her escape and recapture, in the military headquarters where she is imprisoned and he newly posted. Her ordeal and their relationship start in 1992 and last until 1995.

While in the camp, she is housed with other prisoners, involved in forced labour and subjected to the same violence as other prisoners. She is, however, also often in Danijel's office, where their relationship slowly develops, both emotionally and sexually. He offers to help her escape the camp, but initially she does not take up the offer. Later on, after he is posted at the military headquarters in Sarajevo, she tries to escape but is captured. Her second attempt at escaping is successful, but this time she deliberately gets herself recaptured and taken to the headquarters in order to spy on the Bosnian-Serb military forces for the benefit of the Muslim forces. At the headquarters, she is housed in a large room where she can paint,

\footnotetext{
11 See Robert M. Hayden, "Imagined Communities and Real Victims: Self-determination and Ethnic Cleansing in Yugoslavia," American Ethnologist 23/4: (1996)1-19.

12 See M.C. Bassiouniet al. "Sexual Violence: An Invisible Weapon of War in the Former Yugoslavia," International Human Rights Law Institute, Occasional Paper No. 1. Chicago: DePaul University, 1996. See also: "United Nations Commission on Human Rights Inquiry, Attachment IX, Annex II - Report on Allegations of Rape, 10 February, 1993; "United Nations Commission of Experts' Final Report, Section IV: Substantive Findings (E.: Detention Facilities; F.: Rape and other forms of Sexual Assault)," United Nations Security Council S/1994/674, 27 May 1994; “United Nations Commission of Experts' Final Report, Annex IX - Rape and Sexual Assault," United Nations Security Council, S/1994/674/Add.2 (Vol. V), 28 December 1994; “United Nations Commission of Experts' Final Report, 1994, Annex IX.A - Sexual Assault Investigation, United Nations Security Council, S/1994/674/Add.2 (Vol. V), 28 December 1994. 13 At the time, it was less known that men were systematically sexually assaulted as well, especially in the war camps, see Dubravka Žarkov, The Body of War: Media, Ethnicity and Gender in the Break-up of Yugoslavia ; "The Body of the Other Man: Sexual Violence and the Construction of Masculinity, Sexuality and Ethnicity in Croatian Media," in Victims, Perpetrators or Actors? Gender, Armed Conflict and Political Violence, eds C. Moser and F. Clark (London: Zed Books, 2001), 69-82.

14 Among the productions by directors from Bosnia and Herzegovina, the best known nationally and internationally is Grbavica (2006) by Jasmina Žbanić which received Golden Bear in Berlin the same year.
} 
and where he regularly comes to spend time with her. She eventually informs Muslim forces about the Serb military's position and plans, and they attack causing heavy casualties. When Danijel finds out that she was the source of information, he shoots her, and then turns himself in to the UN peacekeepers, declaring: "I am a criminal of war."

Just before the film was completed and released, there was a huge controversy in Bosnia ${ }^{15}$ when the news broke that Jolie's film depicts a Muslim woman falling in love with a Serb rapist in the camp. Women's organizations and NGOs fiercely protested against its screening. However, after the actual plot was made public and the film screened, there was an equally dramatic turn-around. With very few exceptions, the film and the director were highly praised for the result. ${ }^{16}$

A comment often made about the film concerned its "authenticity": it was argued that the film showed the violence against civilians in the city and in the camp "the way it really was." The media also reported Jolie's accounts of her thorough research and many conversations with women, including actual war camp survivors: she wanted the scenes in the camp to resemble real life as closely as possible. She has certainly succeeded in this. The scenes of camp violence (from rape, physical violence, stripping prisoners naked, forcing them to sing, to using prisoners as human shields and other violent and humiliating practices) are clearly based on documents and experiential evidence, as recorded by many fact-finding missions in Bosnia. ${ }^{17}$

For the very same reason, the film was subjected to criticism in Serbia and the Republika Srpska where Jolie was accused of demonizing Serbs. Her visit to Serbia for the Belgrade premiere was cancelled, apparently for "security reasons." Jolie, however, explicitly stated in her TV interviews that by telling the story of violence and of abandonment of Bosnia by the international community, she wanted to make them "aware of what happened" and "remind people." The awareness-raising objective of the film is supported by the fact that it was made in two languages, English and Bosnian, with actors from the former Yugoslavia in both versions. The English-language version, as we will argue, is made for an international - and predominantly US - audience.

\section{In the land of innocence and evil: on cinematic borrowing}

Narrative-wise, the film has two main, interwoven plots - one about the relationship between a woman and a man, and another about war rape - that follow a rather classical, linear progression towards the narrative resolution. ${ }^{18}$ The plots, and the resolution, as noted earlier, depend on the heavy borrowing of tropes from several film genres, from literature, as well as from real life experiences of women living through war.

\footnotetext{
${ }^{15}$ The paragraph relies on the information from a number of film reviews and web-based sources which praise and criticize the film. Among them are: www.filmschoolrejects.com/reviews/review-in-the-landof-blood-and-honey-angelina-jolie-rlevi.php (accessed 20 January 2012); www2.macleans.ca/2012/01/20/angie-meet-gina $\% \mathrm{E} 2 \% 80 \% 94$ the-new-warrior-queen/ (accessed 20 January 2012); www.washingtontimes.com/news/2012/jan/12/movie-review-in-the-land-of-bloodand-honey/?page=all (accessed 12 January 2012); www.belgraded.com/angelina-jolie-serbia-bosniabelgrade (accessed 20 January 2012); www.guardian.co.uk/film/2011/dec/16/angelina-jolie-bloodhoney-bosnia (accessed 16 December 2011).

${ }^{16}$ See Elissa Helms, "Rejecting Angelina: Bosnian War Rape Survivors and the Ambiguities of Sex in War," Slavic Review 73/3 (2014): 612-634.

${ }^{17}$ See especially the United Nations Commission of Experts' Final Reports (1994).

${ }^{18}$ Eleftheria Thanouli, "Post-Classical Narration. A New Paradigm in Contemporary Cinema."
} 
There are three specific instances of cinematic borrowing. First, Jolie replicates scenes that are the absolute marker of Holocaust movies ${ }^{19}$ (Haggith \& Newman, 2005) as a specific film genre: urban scenes of German soldiers entering high buildings, running up the stairs, shouting and banging on doors, pushing people down the stairs with gun batons and killing some on the way, followed by scenes on the streets with uniformed soldiers herding civilians into groups for deportation, frantic women with babies in their arms and resigned old men wearing glasses, carrying small suitcases.

In Jolie's film we see precisely the same scenes twice, at the very start of the film, and halfway into the plot. However, instead of German soldiers, there are Serb soldiers; instead of Jewish civilians, there are Muslims. This particular cinematic borrowing is not incidental. It creates an unmistakable parallel with something very familiar to the US movie-going audience and general population: it tells the story of the Bosnian war as Holocaust story. The representational effect of such Holocaust scenes is twofold. On the one hand, the Nazi-Jew opposition creates an ultimate separation between the victim and the perpetrator, establishing the total innocence and powerlessness of the victim and the relentless, murderous, genocidal machinery of destruction of the perpetrator. In this film there is no space to see Bosnian Muslims in any way other than as absolute victims. Even when they take part in the fighting later in the film, it is framed as a reaction/resistance to victimization. On the other hand, following the dominant western narrative of World War II, according to which western powers, the US in particular, intervened and entered the war to save the world from the murderous Nazi machinery (rather than for reasons of a more self-interested nature), the Holocaust parallel creates the same justificatory rhetoric for the US intervention in the Bosnian war. ${ }^{20}$ This representation simultaneously depicts the US as the righteous player that takes up arms against the evils of the world and defends the innocent, and as the military player capable of stopping the carnage simply because it has the means.

Given that one of the points Jolie repeatedly made in interviews and in the film was that the US and the world failed to intervene in time to save the victims, this parallel with the Holocaust is especially poignant. It emphasizes that - as in the case of World War II - the world powers had been aware of the extermination of Jews/Bosnian Muslims long before they decided to do something about it. This representational parallel between the Holocaust and violence against Muslim civilians in the Bosnian war is yet another indication that the film is made predominantly with a US audience in mind. In the US the Holocaust stands for the ultimate genocide in world history. Other genocides around the world (in Cambodia or Rwanda, for example) could and would never have the same symbolic effect in producing two separate categories - the evil and murderous Nazi/Serb military machinery on the one hand, and the innocent, victimized Jewish/Muslim civilians on the other.

Those images are compounded in Jolie's film by marking the victim not just as a civilian, but also as urban and civil: Ajla is a painter, an artist. Against her urban, cultured, gentle personality stands Danijel and other Serb soldiers, who are not just represented as being from a rural (read: backward) background, but are also ignorant and uncultured: they either explicitly state that they have never been in an art museum, or clearly have no clue as to how to look at art works. In addition, from the very beginning, Danijel wears a uniform. When before the war he and Ajla meet in a dance club, she appears in a lovely summer dress and he in a police uniform while off duty. The narrative function of the uniform in a peacetime civilian

\footnotetext{
${ }^{19}$ See Toby Haggith \& Joanna Newman (eds.), Holocaust and the Moving Image. Representations in Film and Television since 1993 (London,/New York: Wallflower Press, 2005).

${ }^{20}$ For the similar argument, see Stephen Harper, "History is Screaming at Us': Humanitarian Interventionism and the Popular geopolitics of the Bosnian War in Leigh Jackson and Peter Kosimnsky's Warriors."
} 
space such as a dance club is to mark Danijel as non-civilian, as much as his artistic ignorance marks him as un-civil.

With the civilian being a woman and the uniformed person being a man, dominant gender notions of female vulnerability and male power come into play. In the context of ethnicization, such notions of gender intersected with ethnicity to produce specific, collectivizing effects: feminized, Muslim, cultured, civilian victim versus masculinized, militarized, primitive, Serb perpetrator; this opposition symbolically represents all Muslims versus all Serbs of that war, not just the two individual film protagonists.

This gendered-cum-ethnicized representation is apparent in yet another act of cinematic borrowing, this time from some of the ex-Yugoslav cinematic productions. There is a scene "In the Land of Blood and Honey" where Danijel's father - who is the highest-ranking commander of the Bosnian-Serb military formation in the city - holds an emergency meeting in the headquarters. A live musician playing accordion is also present. After having imbibed ample amounts of alcohol, Danijel's father sings drunkenly, empties glasses and breaks them with his bare hands. This scene of primordialized bohemianism is not just irredeemably essentialist in its representation of this particular protagonist; it is actually the infamous form of representation and self-representation for Gypsies, Serbs and other ex-Yugoslav "southerners," as the proverbial "Balkanians" in a number of ex- and post-Yugoslav films. From I even Met Happy Gypsies (Aleksandar Petrović, 1967) ${ }^{21}$ of the late 1960s to Underground (Emir Kusturica, 1995), ${ }^{22}$ Yugoslav, post-Yugoslav and international directors have created a vast variety of the drinking-glass-breaking-singing-followed-by-live-(Gypsy)-male-band scenes. As already noted, Maria Todorova (1997) has coined the concept of Balkanism to mark such associations of primitivism, ${ }^{23}$ violence and masculinity in western cultural and political representations of the Balkan region. ${ }^{24}$ As the above-mentioned films attest, and as Dina Iordanova ${ }^{25}$ and a number of Yugoslav, post-Yugoslav and other international authors have noted, in cinematic productions Balkanism is not just a western representation but also, very much a self-representation. ${ }^{26}$

Balkanism is also closely associated with patriarchy. In Jolie's film patriarchy is not only depicted through the $20^{\text {th }}$ century feminist lens - the rule of men over women - but also through the classical 19th century depiction of a male patriarch who rules over his male off-

${ }^{21}$ For a long time, this was one of the most famous Yugoslav films internationally, as it won the Special Grand Prize of the Jury at the Cannes Film Festival in 1967 and was nominated for Oscar in 1968.

${ }^{22}$ Underground was awarded a Golden Palm at the Cannes Film Festival in 1995, as well as a few US awards.

${ }^{23}$ Maria Todorova, Imagining the Balkans.

${ }^{24}$ The title of the film plays with the same essentialist notions of the region as a place where wild passions - be it in war or in love - are the order of the day. The claim that the word "Balkans" combines two Turkish words that mean "blood" and "honey" is an utter fabrication.

${ }^{25}$ Dina Iordanova, "Conceptualizing the Balkans in the Film." Slavic Review 55/4 (1996): 882- 890;

Cinema of Flames: Balkan Film, Culture, and the Media (London: British Film Institute, 2001); "Intercultural Cinema and Balkan Hushed Histories," New Review of Film and Television Studies 6/1 (2008):5-18.

${ }^{26}$ For a critique of representations and self-representations of Balkanism in the regional cinema, see Iordanova's work (footnote 25). For post-Yugoslav authors, see especially work by Milena Marinkova, "Po-co-co Balkans. Dancing Bears and Lovesick Donkeys, Bouncing Mines and Ethnic Conflict in Two Films from the Region"; Jurica Pavičić, "Cinema of Normalization': Changes of Stylistic Model in post-Yugoslav cinema after the 1990"; Mario Slugan," "Some Methodological Concerns regarding the Study of Balkanism in Cinema," Unpublished article, 2011.

http://lucian.uchicago.edu/blogs/theslavicforum/files/2011/12/SLAVICFO-

RUM_2011_SLUGAN_PUBLICATION.pdf (accessed December 1, 2011). 
spring with the same violence. In one scene Danijel's father slaps his son violently for disobeying him by keeping Ajla, a Muslim woman, as his lover. After receiving the blows Danijel almost folds into himself, making himself small, subordinate and pitiful - the total opposite of the upright, commanding figure he is in his military unit, among his own subordinates.

The third cinematic borrowing comes from the Cold War movies. Danijel's father is depicted as the embodiment of a Russian-cum-Soviet military man - complete with the fur hat, long, black, leather coat and ideological monologues (in this case, the worse examples of nationalist propaganda narratives of Serb historic victimhood). The basic premise of the US Cold War movies was the portrayal of the clash of worldviews, or of civilizations: brainwashed, ideological zealots ready to obliterate the US with a flip of a (nuclear) switch, in an autocratic, brutal, communist society, contrasted with the free-thinking people of western democracy. ${ }^{27}$ In Jolie's film the zealotry and brutality are depicted as essential characteristics of Serbs. There is no free, democratic western society as a desirable opposition in the movie, however. Rather, the point is to show an absence of western help to defeat the zealots and defend the innocent victims.

\section{Antiquity, ambiguity and silence: on literary and experiential borrowings}

This film is meant to be a war story. But its genre is far from clear-cut. As noted earlier, the war story is intertwined with something that may look like a tragic love story, modelled on Romeo and Juliet. In a shockingly unashamed revocation of Juliet's anguish: "Oh Romeo, Romeo, wherefore art thou Romeo? Deny thy father and refuse thy name...Oh, be some other name," 28 Jolie makes Danijel ask Ajla: "Why couldn't you be born a Serb?" This borrowing of some of the most famous sentences in western literature is all the more significant because Juliet's words were written almost exactly 500 years before the war in the former Yugoslavia. The ancient sentiments concerned with bloodlines and belongings are thus made to matter to Serbs, as Ajla earlier already stated that she was brought up to value all people equally, regardless of their ethnicity.

At the same time, while in Romeo and Juliet there is no doubt that the two young people are truly and deeply in love, the relationship between Ajla and Danijel is far more complicated. Speaking of classical movie narratives, Thanouli notes that they are most often based on the interweaving of two plots: "the formation of the heterosexual couple with the undertaking of the mission." 29 The "formation of the heterosexual couple" is an appropriate expression here, as the relationship between Danijel and Ajla, while certainly undergoing formation as a couple, leaves open the question as to what kind of a couple they are. Sex is part of it, no doubt. The film offers a number of carefully crafted sex scenes between the two main protagonists: from gentle sex to scenes where Danijel is sexually violent. All of these scenes, however, offer a cinematically rather boring, mainstream representation of heterosexual sex. He is on top, while she is showing her satisfaction by sighing with open mouth and closed eyes under him, or she displays her alienation by gazing emptily away, again positioned under him. But is their relationship based on sexual passion, and/or romantic love, as the Romeo and Juliet reference would suggest? Neither of those, it seems, or, maybe more precisely: not equally for each of them.

In the war camp, where their sexual relationship develops, Ajla at first rejects Danijel's advances, despite the fact that before the war there was attraction. Later on, she comes to

\footnotetext{
${ }^{27}$ Tony Shaw, Hollywood's Cold War (Edinburgh: Edinburgh University Press, 2007).

28 William Shakespeare, Romeo and Juliet. The Illustrated Stratford Shakespeare (Bath: Reed Editions, 1597/1982), 708.

${ }^{29}$ Eleftheria Thanouli, "Post-Classical Narration. A New Paradigm in Contemporary Cinema": 185.
} 
him for emotional support and protection, after being subjected to physical violence by other soldiers. It is implied that she attaches herself to him, or accepts his advances, as a survival strategy. In other words, Jolie's narrative suggests that Ajla is a woman who has entered the relationship under duress, to save herself from the fate of other women in the camp: everyday rape, torture and violence, humiliation and deprivation of basic necessities. But there is no clear-cut conclusion here. From Ajla's side, there was a clear emotional attachment, maybe even love, at the beginning of the relationship, during peacetime. In the camp and later in the headquarters, she does not appear totally indifferent towards Danijel. However, Jolie does not develop Ajla's side of the story as a love story. Actually, Danijel is the only one who speaks about love in this movie, and who performs classical manly acts of protecting his woman (declaring her "his property," thus off limits to the other soldiers), and later of avenging the wrongs done to her (killing a fellow soldier who raped her). He is also the one who appears tormented by their relationship throughout the film, because of their different ethnicities. She is mainly silent, often inert, never uttering any words of love. Her silence may be seen as underlining the suggestion that she develops a relationship with him, because it was the lesser of all of the evils she could potentially face. Nevertheless, the scenes of gentleness between the two protagonists do indicate that Ajla's relationship towards Danijel carries an element of emotional attachment, not just sex-for-protection, or later, patriotic self-sacrifice. This leaves ample space for ambiguity.

The way we read the narrative plot, however, is less about ambiguity created in the story and more about the indecision of the director. In other words, the impression is not that the director wanted to create narrative ambiguity, in order to open up a space for different possibilities in the development of the story. Rather, it seems that Jolie herself did not really know in which direction to take the story of "the formation of the heterosexual couple," and was stuck between several possible scenarios, none of which were properly developed: the "sexfor-survival" scenario, "inter-ethnic love story" and the "sex-as-patriotic duty/sacrifice" scenario. In all of those scenarios love, sex and emotional attachments could have been systematically developed, but that did not happen. Instead, as we argue below, Jolie makes specific narrative choices that undermine any possibility of a deeper cinematic examination of the ambiguity of human emotions and relationships in the context of war and violence marked by (or even, reduced to) ethnicity. This indicates a lack of inspiration and originality in the script of the film, but more importantly, it indicates a rather overwhelming laziness of the mind and absence of utopian imagination on the parts of the director and screen-writer, who simply went along with mainstream US definitions of the causes, dynamics and, ultimately, consequences of the war in Bosnia.

The "sex-for-survival" scenario is a well-known phenomenon, especially in the context of violence, war or deep social deprivation. In this particular case, this scenario carries the rather dangerous assumption that women's experiences of war all over the globe are the same. Indeed, the positioning of the female protagonist within the strategic war-survival relationship with a man was not something that typified women's experiences of war in Bosnia. And this is where we note experiential borrowing: Jolie projected onto Bosnia the stories about women and war from other geographies, other spaces.

One thing needs to be clarified here. We are not arguing that no woman in Bosnia opted for a strategic sexual relationship with a man in wartime. Quite a number of stories about such relationships of local women and international peacekeeping forces are well known. ${ }^{30}$

\footnotetext{
${ }^{30}$ See, for example, discussion about diversity of (consensual, strategic, forced and other, more ambiguous) sexual relationships between peacekeepers and local woman, in the context of UN politics of sexuality, by Olivera Simić, Regulation of Sexual Conduct in UN Peacekeeping Operations (Berlin: Springer,
} 
However, in the context of war camps and sexual violence, such relationships did not characterize the Bosnian war. None of the documents on wartime rape and other forms of sexual violence in ex-Yugoslavia (from official fact-finding missions, to grey NGO documents) that we came across point to women deliberately staying with (para)military personnel as a personal war-survival strategy in Bosnia; not even in single-person imprisonment in individual homes, which was also used in the war in Bosnia. The wartime imprisonment of women for purposes of sexual violence and exploitation is systematically described in terms of forced, not as strategic choices made by women. Again, we do not argue that no single woman has ever used this strategy. We argue, rather, that - within the gendered patterns of violence and survival during the Bosnian war - this particular form of strategic sexual attachments was not in any way a significant feature of the war.

Importantly, individuals attaching themselves to soldiers and military commanders, in order to save themselves from sexual violence within military units, has been a well-documented and - among academics and activists - well-known strategy of young women/girl-soldiers in several African conflicts, where women formed a large part of the paramilitaries, especially in Sierra Leone and Liberia. ${ }^{31}$ Some of those strategic attachments were initially also forced; i.e. young girls were forcibly abducted, raped and given to military commanders or soldiers in sexual (and other forms of) slavery. Others have been strategic survival choices from the start. Similar practices are also known in South Asia, where, during the Partition, thousands of women were raped, abducted and then taken (formally or informally) as wives by the abductors. Social and geo-political norms have left these women little choice but to stay with the rapist/abductor. ${ }^{32}$

This is not to say that no parallels exist at all between gender-specific forms of war sexual violence in Bosnia and other parts of the world. Neither war rape nor forced impregnation

2012). The UK film Warriors actively uses such relationships of local women and UK peacekeepers in its narrative plot.

${ }^{31}$ See, for example Asher's (2004) edited volume of narratives by Liberian and Sierra Leone women exchild/youth soldiers: Face_WSLOT Women See Lot of Things. Female Ex-child Combatants in Sierra Leone (The Hague: Bodylab Foundation, 2004); Chris Coulter, "Female Fighters in the Sierra Leone War: Challenging Assumptions?." Feminist Review 88/1 (2008): 54-73; Chris Coulter, Bush Wives and Girl Soldiers: Women's Lives through War and Peace in Sierra Leone (New York: Cornell University Press, 2009); Christine Gervais \& Myriam Denov, "Negotiating (in)Security: Agency, Resistance, and Resourcefulness among Girls Formerly Associated with Sierra Leone's Revolutionary United Front," SIGNS 32/4 (2007): 885-910; Augustine S.J. Park, “"Other Inhumane Acts": Forced Marriage, Girl Soldiers and the Special Court for Sierra Leone," Social \& Legal Studies 15(3) (2006): 315-337., Janneke Van Gog, Coming back from the Bush: Gender, Youth and Reintegration in Northern Sierra Leone (Leiden: African Studies Centre, 2008); Irma Specht, "Red Shoes: Experiences of Girl-combatants in Liberia." (Geneva: ILO, 2006), www.ilo.org/employment/Whatwedo/Publications/WCMS_116435/lang--en/index.htm (accessed 21 January 2012). It is also worth noting that the Special UN Court for Sierra Leone war crimes was the first to try and convict war criminals - among others, Charles Taylor - for recruiting and abducting child soldiers, including girls, as well as for the practice of forced marriage of girls to paramilitary leaders. Interestingly, according to Bouwknegt, Jolie personally attended some of the Charles Taylor trial sessions. See T. Bouwknegt, “Tristes Tropiques Africain. African Atrocity Trials as Oral History," paper delivered at the international seminar "Regional and International Discourses on Deliveries of Justice in Former Yugoslavia: Histories, Meanings and Narratives" (NIAS, Wassenaar, The Netherlands, 23 April 2012). It is difficult to know whether the knowledge about strategic sexual relationships comes from following this particular trial, but it certainly was not something she could have read in the UN or NGO reports on Bosnia.

32 See Urvashi Butalia, "Community, State and Gender: On Women's Agency during Partition," Economic and Political Weekly (24 April 1993); "A Question of Silence: Partition, Women and the State," in Gender and Catastrophe, ed. R. Lentin (London \& New York: Zed Books, 1997), 92-110. 
were unique to Bosnia - even though some of the literature would have us believe so. ${ }^{33}$ However, while there are gendered similarities of patterns of sexual violence against women in war, this does not imply erasure of the differences and contexts. Equally, the absence of specific patterns of violence does not mean that Jolie is not allowed to make them a feature of her film. But the question remains as to the function of such a narrative element within the overall narrative of the relationship between the two main protagonists.

Jolie changed the dynamics of this relationship in the second half of the film, offering yet another possible interpretation of the "heterosexual coupling": Ajla's deliberate return to Danijel (and thus acceptance of detention) is framed as an act of politically motivated, personal sacrifice, a patriotic act for the benefit of the Muslim forces fighting against Danijel's Bosnian-Serb military unit. With this spy-genre twist, the film narrative continues the ambiguity and unevenness in Ajla's and Danijel's sexual and emotional relationship, showing ever sharper differences in their emotional involvement. Daniel continues with explicit and ever more intense expressions of love as well as tormenting questions about the present state and the future of their relationship, which often enough turns violent. Ajla is mostly silent and guarded in showing any kind of emotion and reflects only once on the nature of her involvement with Danijel. This asymmetry in the way Ajla and Danijel treat their relationship may be seen as deliberately created by the director and screenwriter. This is because in the film narrative the nature of this relationship, at that moment, may be clear to Ajla: she is there to learn important secrets and convey them to Muslim fighters, and in the meantime she seduces Danijel and is dependent on him. But her self-chosen imprisonment is extremely long: the film narrative places her in the headquarters from spring 1993 throughout 1994, to summer 1995, when she finally gathers important intelligence for the Muslim forces. For more than two years Ajla paints and waits for Danijel, and only in the last weeks does she learn something worthwhile about his unit's military movements. Even if self-chosen, this length of time raises doubts as to whether this imprisonment was motivated by patriotism alone. The problem is that we do not really know what motivates Ajla's actions and inactions through the film, because she is mostly silent and inarticulate. Apart from two instances, in which she speaks of being ashamed of staying with Danijel while others are murdered, and of how in her family she was taught to judge people by their human qualities rather than by ethnicity or religion, we see a female subject whose (in)action seems to be generated by inertia rather than by any strong, inner motivation. Or rather, we are given hardly any cinematic evidence of the motivation or explanation for her actions.

The representational effects of all those cinematic and narrative choices are the two rather uneven life stories of the main protagonists. Ajla is given a personal, pre-war history: we see her paint, meet her family, we see her live an urban, modern, civilian, cultured life. Through this history her world is embedded in peacetime Sarajevo - she is part of that city. But when the war starts, she fades as a character, and her presence on the screen is filled with silences. This may have been the director's deliberate choice, a cinematic way of stating that horrors such as Bosnian war camps and war rape are unspeakable; that being in a war camp is best survived by making oneself mute and numb; that explicit expressions of emotional doubts and torments are a privilege of those in power - like Danijel - who are free to express their love because they do not have to face the life-or-death consequences of those expressions. But the effect of this way of telling Ajla's story is her rather passive presence on the screen.

\footnotetext{
${ }^{33}$ For an excellent critique of such approaches, see Rhonda Copelon, "Surfacing Gender: Reconceptualizing Crimes against Women in Time of War," in Mass Rape: The War against Women in Bosnia-Herzegovina, eds A. Stiglmayer et al. (Lincoln and London: University of Nebraska Press, 1993), 197-218.
} 
Unlike Ajla's, we never see Danijel's peacetime life history, nor do we meet his peacetime family. Actually, we learn that even in peace he is not a civilian: he attends civilian occasions (the dance, at the start of the film) in uniform; he follows a long family tradition of policing - not as a personal choice of profession, though, but rather due to not having the "privilege of choice," in his own words. As for Danijel's family, we only see his father, who is at the same time his military commander in the Bosnian war. We hear about the family's history of war, through the story of the murder of his father's mother - by Muslims - in World War II. Danijel's father's dialogues with him, other soldiers and Ajla, furthermore, are crafted after the worst political exposés of radical, nationalist Serb political parties - full of racist, murderous intentions and effects. This, presumably, constitutes Jolie's lesson to the cinema audience about the causes of the war: following the dominant international narrative of "a history of ethnic hatred," she uses Danijel's father's relentless hatred towards Muslims as the only explanation of the causes of the Bosnian war. This political narrative has been challenged by many authors, but apparently, by 2010 when Jolie started working on the film, she had not come across any other analyses of the causes of the violent disintegration of the former $\mathrm{Yu}$ goslavia, but the deep-seated, historic hatred of Serbs towards Muslims.

Danijel's life story, at moments, seems to offer a counter-narrative to such essentializing fantasies. For example, he continuously speaks against the war. But he still takes part in it. He - apparently under Ajla's civilizing influence - does not use his sharpshooting skills to shoot civilians. But he is a commander of the camp where atrocities against civilians are committed before his very eyes. He defies his father by keeping Ajla with him, but he kills her in the end. So, every element of a potential counter-narrative to the Serbs' "ethnic hatred" of Muslims and brutal, militarized masculinity of Serbs is rebuffed, and Danijel at the end appears as a weak opportunist. Even when he surrenders himself to the international peacekeepers, stating "I am a criminal of war," we can read this statement in very different ways. It could have the qualities of redemption: here is a Serb military man who has acknowledged (albeit unwittingly and indirectly) his participation in war crimes and accepted personal responsibility - something we haven't seen much of among any of the convicted war criminals at ICTY. But it could be easily read in another way; it could actually be saying: look, even the best of the Serbs (the best that are found in this particular film) have done the worst things.

\section{Towards conclusions: ontologies of violence}

The opening questions of this article concerned the ontological subject positions of the main protagonists and the ways in which they are produced through violence, through intersections of gender and ethnicity. The life stories of the two main protagonists in the film show how the subject positions are created: Ajla actively lived in peacetime, but she paled into ambiguous silences during the war; Danijel had no cinematic life in peacetime, but was actively, though confusedly, engaged in the war. If we take those two protagonists as symbolic of their respective ethnic communities - for this is precisely the function they fulfil in this movie there is a larger narrative here that frames those two life stories. It is a narrative about how violence constructs gender and ethnicity in time and space.

The Muslim woman and the Serb man share only one short cinematic moment of multiethnic time and space - in the past, in a peacetime Sarajevo dance club. Beyond that, throughout the film, every relationship and every act of violence is not just ethnic, but thoroughly ethnicized. Furthermore, "the Serbs" we see in the film are, apart from one occasion, exclusively military men, many of them sadistic. The only other characters who could be Serbs are a few civilian, excessively made-up, loud, drinking young women joining the soldiers, entering the war camp and reacting with equally sadistic enjoyment to the violence against older Muslim women camp prisoners. This means that the film approaches ethnicity in quite the 
same manner as the Serb nationalists it presumably deplores - seeing it as the ultimate mode of being. The two main narrative plots - the formation of the heterosexual couple and the war violence - are both constituted and developed through ethnicization towards their respective dramatic ends. Danijel's murder of Ajla, at the end of the film, is the symbolic act that seals the ethnicized ontological subject positions of the film's protagonists, displaying Jolie's failure to critically engage with essentialist notions of ethnicity.

\section{Acknowledgements}

This research is part of a larger project that Dubravka Zarkov conducted as a recipient of the NIAS Fellowship, February-June 2012, as a coordinator of a research group working on a joint project "The Real and the Imagined in Contemporary Balkans". For more information, see: https://nias.knaw.nl/themegroup/the-real-and-the-imagined-in-the-contemporary-balkans/. Rada Drezgic worked on this paper as part of the project No. 41004, financed by the Ministry of Education and Science of the Republic of Serbia within the framework of integrated and interdisciplinary research for the period 2011-2014.

\section{References}

Asher, M. (ed.). Face_WSLOT Women See Lot of Things. Female Ex-child Combatants in Sierra Leone. The Hague: Bodylab Foundation, 2004.

Bakic-Hayden, Milica \& Hayden, Robert M. “Orientalist Variations on the Theme 'Balkans': Symbolic Geography in Recent Yugoslav Cultural Politics.” Slavic Review 52/1 (1992):116.

Bassiouni, M.C. et al. "Sexual Violence: An Invisible Weapon of War in the Former Yugoslavia.” International Human Rights Law Institute, Occasional Paper No. 1. Chicago: DePaul University, 1996.

Bouwknegt, T. "Tristes Tropiques Africain. African Atrocity Trials as Oral History.” Paper delivered at the international seminar "Regional and International Discourses on Deliveries of Justice in Former Yugoslavia: Histories, Meanings and Narratives", NIAS, Wassenaar, The Netherlands (23 April 2012).

Butalia, Urvashi. "Community, State and Gender: On Women's Agency during Partition." Economic and Political Weekly 24 April 1993.

"A Question of Silence: Partition, Women and the State." In Gender and Catastrophe, ed. R. Lentin, 92-110. London \& New York: Zed Books, 1997.

Butler, Judith. "Sexual Politics, Torture, and Secular Time." The British Journal of Sociology 59/1 (2008): 1-23.

Copelon, Rhonda. "Surfacing Gender: Reconceptualizing Crimes against Women in Time of War." In Mass Rape: The War against Women in Bosnia-Herzegovina, eds A. Stiglmayer et al., 197-218. Lincoln and London: University of Nebraska Press, 1993.

Coulter, Chris. "Female Fighters in the Sierra Leone War: Challenging Assumptions?" Feminist Review 88/1 (2008): 54-73.

Bush Wives and Girl Soldiers: Women's Lives through War and Peace in Sierra Leone. New York: Cornell University Press, 2009.

Gervais, Christine \& Denov, Myriam. "Negotiating (in)Security: Agency, Resistance, and Resourcefulness among Girls Formerly Associated with Sierra Leone's Revolutionary United Front." SIGNS 32/4 (2007): 885-910.

Haggith, Toby \& Newman, Joanna (eds.). Holocaust and the Moving Image. Representations in Film and Television since 1993. London,/New York: Wallflower Press, 2005. 
Harper, Stephen. “"History is Screaming at Us': Humanitarian Interventionism and the Popular geopolitics of the Bosnian War in Leigh Jackson and Peter Kosimnsky's Warriors." Review article, 16 June 2011. http:/ / www.relativeautonomy.com/2/post/2011/06/historyis-screaming-at-us-humanitarian-interventionism-and-the-popular-geopolitics-of-the-bosnian-war-in-leigh-jackson-and-peter-kosminskys-warriors.html (accessed 6 June 2011).

Hayden, Robert M. "Imagined Communities and Real Victims: Self-determination and Ethnic Cleansing in Yugoslavia." American Ethnologist 23/4: (1996)1-19.

Heathershaw, John \& Lambach, Daniel. "Introduction: Post-Conflict Spaces and Approaches to Statebuilding." Journal of Intervention and Statebuilding 2/3 (2008): 269-289.

Helms, Elissa. "Rejecting Angelina: Bosnian War Rape Survivors and the Ambiguities of Sex in War." Slavic Review 73/3 (2014): 612-634.

Iordanova, Dina. “Conceptualizing the Balkans in the Film.” Slavic Review 55/4 (1996): 882890.

. Cinema of Flames: Balkan Film, Culture, and the Media. London: British Film Institute, 2001.

"Intercultural Cinema and Balkan Hushed Histories." New Review of Film and Television Studies 6/1 (2008):5-18.

Jhally, Sut. Reel Bad Arabs: How Hollywood Vilifies a People. Media Education Foundation, 2006.

Jazairy, El Hadi “Cinematic Landscapes in Antonioni’s L'Aventura.” Journal of Cultural Geography 26/3 (2009): 351-369.

Pavičić, Jurica. "Cinema of Normalization': Changes of Stylistic Model in post-Yugoslav cinema after the 1990." Studies in Eastern European Cinema 1/1 (2010): 43-55.

Marinkova, Milena. "Po-co-co Balkans. Dancing Bears and Lovesick Donkeys, Bouncing Mines and Ethnic Conflict in Two Films from the Region." Third Text 24/4 (2010):457469.

Petrović, V. (forthcoming) Camera Obscura in Bijeljina, War Crimes Photos and Delivery of Justice in Serbia.

Park, Augustine S.J. "“"Other Inhumane Acts": Forced Marriage, Girl Soldiers and the Special Court for Sierra Leone." Social \& Legal Studies 15(3) (2006): 315-337.

Said, Edward. Orientalism. New York: Vintage Books, 1994.

. "Orientalism Once More." Development and Change 35/5 (2004):869-879.

Shakespeare, William. Romeo and Juliet. The Illustrated Stratford Shakespeare. Bath: Reed Editions, $1597 / 1982$.

Shaw, Tony. Hollywood's Cold War. Edinburgh: Edinburgh University Press, 2007.

Simić, Olivera. Regulation of Sexual Conduct in UN Peacekeeping Operations. Berlin: Springer, 2012.

Slugan, Mario. "Some Methodological Concerns regarding the Study of Balkanism in Cinema." Unpublished article, 2011. http://lucian.uchicago.edu/blogs/theslavicforum/files/2011/12/SLAVICFORUM_2011_SLUGAN_PUBLICATION.pdf (accessed 1 December 2011).

Specht, Irma. "Red Shoes: Experiences of Girl-combatants in Liberia." Geneva: ILO, 2006. www.ilo.org/employment/Whatwedo/Publications/WCMS_116435/lang--en/index.htm (accessed 21 January 2012).

Thanouli, Eleftheria. "Post-Classical Narration. A New Paradigm in Contemporary Cinema." New Review of Film and Television Studies 4/3 (2006):183-196.

Todorova, Maria. Imagining the Balkans. Oxford: Oxford University Press, 1997.

Van Gog, Janneke van. Coming back from the Bush: Gender, Youth and Reintegration in Northern Sierra Leone. Leiden: African Studies Centre, 2008. 
Žarkov, Dubravka. "The Body of the Other Man: Sexual Violence and the Construction of Masculinity, Sexuality and Ethnicity in Croatian Media." In Victims, Perpetrators or Actors? Gender, Armed Conflict and Political Violence, ed. C. Moser and F. Clark, 69-82. London: Zed Books, 2001.

The Body of War: Media, Ethnicity and Gender in the Break-up of Yugoslavia. Durham and London: Duke University Press, 2007.

. "Cinematic Representations of the Bosnian War: De Enclave and the Ontologies of Unrecognizability.” In Post-Yugoslavia. New Cultural and Political Perspectives, ed. Abazovic, D. and M. Velikonja, 162-197. London: Palgrave MacMillan, 2014a.

"Warriors: Cinematic Ontologies of Bosnian War." European Journal of Women's Studies 21/2 (2014b): 180-193. 